Proceedings

\title{
COVID-19: A Game-Changer for Higher Education Environ- ment at Coimbra Health School
}

\author{
Marta Vasconcelos-Pinto ${ }^{1,2 *} ¥$, Fernando Mendes, $^{, 3,4,5,6} ¥$, Célia Gomes ${ }^{7}$, and João José Joaquim ${ }^{8}$
}

Publisher's Note: MDPI stays neutral with regard to jurisdictional claims in published maps and institutional affiliations.

\section{(c)}

Copyright: (C) 2020 by the authors. Submitted for possible open access publication under the terms and conditions of the Creative Commons Attribution (CC BY) license (http://creativecommons.org/licenses/by/4.0/).

\author{
1. Politécnico de Coimbra, ESTeSC, DSA, Rua 5 de Outubro - SM Bispo, Apartado 7006, 3046-854 Coimbra, \\ Coimbra, Portugal \\ 2. CISAS, Insittuto Politécnico de Viana do Castelo, Rua da Escola Comercial e Industrial de Nun'Álvares, \\ 4900-347, Viana do Castelo, Portugal \\ Politécnico de Coimbra, ESTeSC, DCBL, Rua 5 de Outubro - SM Bispo, Apartado 7006, 3046-854 Coim- \\ bra, Coimbra, Portugal \\ University of Coimbra, Coimbra Institute for Clinical and Biomedical Research (iCBR) area of Environ- \\ ment Genetics and Oncobiology (CIMAGO), Biophysics Institute of Faculty of Medicine, Coimbra, Portugal; \\ 5. University of Coimbra, Center for Innovative Biomedicine and Biotechnology (CIBB), Coimbra, Portu- \\ gal; \\ 6. Clinical Academic Center of Coimbra (CACC), Coimbra, Portugal; \\ 7. Politécnico de Coimbra, ESTeSC, DCC, Rua 5 de Outubro - SM Bispo, Apartado 7006, 3046-854 Coimbra, \\ Coimbra, Portugal \\ Politécnico de Coimbra, ESTeSC, DFAR, Rua 5 de Outubro - SM Bispo, Apartado 7006, 3046-854 Coim- \\ bra, Coimbra, Portugal \\ * Correspondence: ; Tel.: +351 239802436 (M.V.P.) \\ $¥$ Both authors contributed equally for the paper
}

\begin{abstract}
Our paper is an overview of the measures implemented at Coimbra Health School (CHS) to restraint the spread of coronavirus disease (COVID-19). CHS is a public higher education institution in Portugal with 1300 students and 200 employees, devoted to teaching in the area of Health Sciences and Technologies. Hereby we summarize the public health actions at higher education, measures taken to prevent the harmful effects of the pandemic and following implications.
\end{abstract}

Keywords: COVID 19; Higher education; Contingency Plan

\section{Introduction}

We are currently experiencing a public health crisis-stricken by the Severe Acute Respiratory Syndrome Coronavirus-2 (SARS-CoV 2), which causes COVID-19. Evidence and worldwide experience add knowledge daily, helping to make collective decisions concerning public health [1].

The unprecedented spread of SARS-CoV2, the high rate of transmission and the collapse of health systems in several countries have made COVID-19 the worst "modern" pandemic [2].

The disease originating in Wuhan, Hubei, China, accelerated undoubtedly. Until December 22, 2020, new COVID-19 cases and deaths has infected millions of humans across 218 countries and territories and continued to increase to approximately 4.6 million new cases and over 79000 recent deaths. These numerous deaths bring the cumulative numbers to over 75 million reported cases and 1.6 million deaths globally since the pandemic [3].

Several researches point out that SARS-CoV2 (and COVID-19) has the following characteristics: (1) a high spread rate (and speed), (2) affects more severely the aged and immunocompromised people (the most vulnerable), and (3) is associated with differential recovery rates in age groups and different countries [4], [5]. 
Following WHO recommendations, all countries should increase their level of organization, alertness and response to identify, manage and care for new cases of COVID-19. Governments should prepare to respond to different public health scenarios, recognizing that there is no single approach to all cases and outbreaks of COVID-19 [6]. Each country must assess the risk and quickly implement necessary measures at the appropriate scale to reduce the transmission of COVID-19, considering the undetermined economic, public and social impacts [7]. Four transmission scenarios were also outlined as a measure to support national management [6].

Several control measures have been taken by countries, in different ways and at specific times, making the response to the pandemic crisis dissimilar, resulting in unequal outcomes in terms of disease incidence and lethality [8]-[10]. Among the strategies implemented worldwide and to the initial confinement and restriction of social contacts were added the isolation of cases and tracking of contacts, as well as measures focused on epidemiological aspects. [11]. Concurrently, and due to the recognized importance to the countries preventive strategy, statistics are reinforced daily, which largely contribute to the definition of characteristics associated with transmission and contagion and a generic evaluation of the effectiveness of measures taken by different governments. It should be highlighted that although the pandemic is global, the response to its threats is local [9].

\section{Crisis Management in the COVID-19 context in Portugal}

Following global guidelines and concerns Portugal, through a decree of the President of the Portuguese Republic, declared the emergency state on March 19, based on a public calamity situation, providing the initial control measures considering the pandemic situation [12]. Following the emergency state and considering the articulation between the Government and the National Health Authorities, measures have been outlined that translate into limitations of rights, freedoms and guarantees, Constitutional support that only the state of emergency can provide. In a first nationally coordinated response, mandatory confinement at home was declared, sanitary cords were established, and a temporary ban on movements and unjustified stays at public roads [13]. Events were suspended, schools and non-essential stores were closed, as well as non-essential travels were forbidden and borders closed [14].

Since then, the level of alert has been adapted to calamity and contingency state in sequence with the positive epidemiological developments. The reverse in case increase trough the adoption of isolation measures and by embracing several protective sanitary policies was primarily achieved [15]-[17]. However, recently and due to the increase of active transmission chains, the emergency state was re-declared [18] and national territory was stratified into risk areas [19].

The National Health Service (SNS) is the structure through which the Portuguese State ensures the right to health for all citizens. The General Directorate of Health (DGS) is the national health authority that, under the guidance of World Health Organization recommendations, in close cooperation with the civil protection entities endorses regulation, guidance, health promotion and disease prevention activities [13].

Health authorities are particularly relevant in an epidemiological crisis condition, providing information on monitoring indicators. DGS is working on a daily basis on the established epidemiological statistics, such as incidence rate; the number of suspected cases, number of confirmed cases, proportion of severe cases; the proportion of cases requiring mechanical ventilation, lethality stratified by sex and age groups, among others [20].

This article was prepared to describe Coimbra Health School's adaptation process, a public higher education institution with approx. 1300 students and 200 employees, devoted to teaching in the area of Health Technologies.

\section{Context of the measures endorsed for higher education}

Scientific and higher education institutions assume a leading role in the creation and dissemination of knowledge in society. 
The General Directorate for Higher Education (DGES) is responsible for ensuring the design, implementation and coordination of policies for higher education, under the governmental supervision of the Ministry of Science, Technology and Higher Education (MCTES) [21].

The first declaration of the emergency state dictated the closure of several sectors of activity, including higher education institutions. Worldwide, distance education attained special attention as the sole possible method of education [22], [23].

The measures taken in is context, considering the relevance of higher education in the economic and social system, aim to establish the guarantee of essential activities and services in scientific and academic institutions (Table 2).

Table 1. State of recommendations to higher education institutions.

\begin{tabular}{|c|c|}
\hline March 16 & $\begin{array}{l}\text { Suspension of face-to-face activities with enhanced operation } \\
\text { by video conference or other electronic means, in order to } \\
\text { guarantee the normal functioning of teaching activities and } \\
\text { the realization of all public evaluations. }\end{array}$ \\
\hline $\begin{array}{l}\text { March } 202020 \text { - Clarification on } \\
\text { essential services to be exempted } \\
\text { from limitations associated with } \\
\text { the "State of Emergency" within } \\
\text { the scope of scientific and aca- } \\
\text { demic institutions }\end{array}$ & $\begin{array}{l}\text { Maintenance of activities carried out by scientific research and } \\
\text { development entities and activities associated with the diagno- } \\
\text { sis and prevention of the new coronavirus and prevention of } \\
\text { COVID-19; permanent maintenance and safety activities; Infor- } \\
\text { mation Technology support activities; services that guarantee } \\
\text { access to food and accommodation in higher education; admin- } \\
\text { istrative and financial services, among others. }\end{array}$ \\
\hline $\begin{array}{l}\text { April } 172020 \text { - Elaboration of } \\
\text { plans for a progressive survey of } \\
\text { the containment measures moti- } \\
\text { vated by the pandemic COVID-19 }\end{array}$ & $\begin{array}{l}\text { Recommendation to draw up plans for the progressive li } \\
\text { of containment measures, encouraging the adoption of di } \\
\text { learning and teleworking processes, but promoting, whe } \\
\text { possible, their gradual and effective combination with fa } \\
\text { face activities, specifically aimed at practical, laboratory c } \\
\text { and final assessment's. }\end{array}$ \\
\hline \multicolumn{2}{|l|}{$\begin{array}{l}\text { April } 30 \text { - Recommendation to sci- } \\
\text { entific and higher education insti- } \\
\text { tutions regarding the cessation of } \\
\text { the state of emergency caused by } \\
\text { the pandemic COVID-19 }\end{array}$} \\
\hline \multicolumn{2}{|l|}{$\begin{array}{l}\text { May } 15 \text { - Recommendation to sci- } \\
\text { entific and higher education insti- } \\
\text { tutions to guarantee the process of } \\
\text { phased and responsible reactiva- } \\
\text { tion of activities in the presence of } \\
\text { students, teachers and researchers }\end{array}$} \\
\hline $\begin{array}{l}\text { stitutions for the preparation of } \\
\text { the academic year of } 2020 / 2021\end{array}$ & $\begin{array}{l}\mathrm{L} \\
\mathrm{g}\end{array}$ \\
\hline
\end{tabular}

November 2 - Recommendation to

scientific and higher education in- Strengthening operational recommendations, maintenance of stitutions to maintain academic the guiding principles the academic year 2020/21 and strategic and scientific activities facing the guidance regarding the social base of higher education and reaggravation of the epidemiologi- covery centred on knowledge and innovation cal situation

Source - own elaboration based on [24].

\section{Emerging Infection Control Committee}

Once it is understood that the real key factor for the success is based on a cooperation system, it is necessary to establish working groups and form leaderships, operating homogeneously and systematically [2]. So, on March 4, in compliance with the Ministers' 
Offices determination, Coimbra Health School created the Emerging Infections Control Committee, aiming to fulfil the preparation of a contingency plan [25].

The commission is responsible for coordinating the contingency plan's implementation and defining the action plan for teaching activities, coordinating efforts and activities with the occupational and environmental health service and with the Regional Health Authorities. Also ensures compliance with the guidelines defined in the plans, acting on any non-compliance and providing information on the epidemiological context in the community.

Facing the emergency scenario was established a strategy from a logistical and organizational standpoint, based on a situational diagnosis of human, material, infrastructure and financial resources. Once verified, the preparation of human resources was reflected to establish the existing limitations [2].

\section{Contingency Plan}

The contingency plan, based on the premises and guidelines of the health authorities, is reviewed and updated according to the evolution of the epidemiological scenario. The following general prevention and health principles were defined:

- Physical distance (minimum of 1,5 meter) between people,

- Mandatory respiratory protocol actions,

- Personal hygiene, focused on frequent hand washing and, if its washing is impracticable, use of handrub alcohol-based antiseptic solution,

- Reinforce of hygiene and environmental measures, with cleaning, disinfection and adequate ventilation of spaces,

- Renewal of air with negative pressure, whenever feasible,

- Use of collective protection equipment such as barrier methods,

- Mandatory use of Personal Protective Equipements (PPE),

- Reinforce and encouragement of self-monitoring of symptoms,

- Use of the StayAway COVID app.

Human and material resources considered essential were identified [2]. Information and training of the academic community campaign were initiated [26].

Aiming effective case management were outlined different action scenarios, whether dealing with a suspected case of COVID-19 on the premises or a confirmed case. Imposed by the health authorities, all institutions have an isolation room for suspected infection cases, in compliance with various structural and functional specifications. 


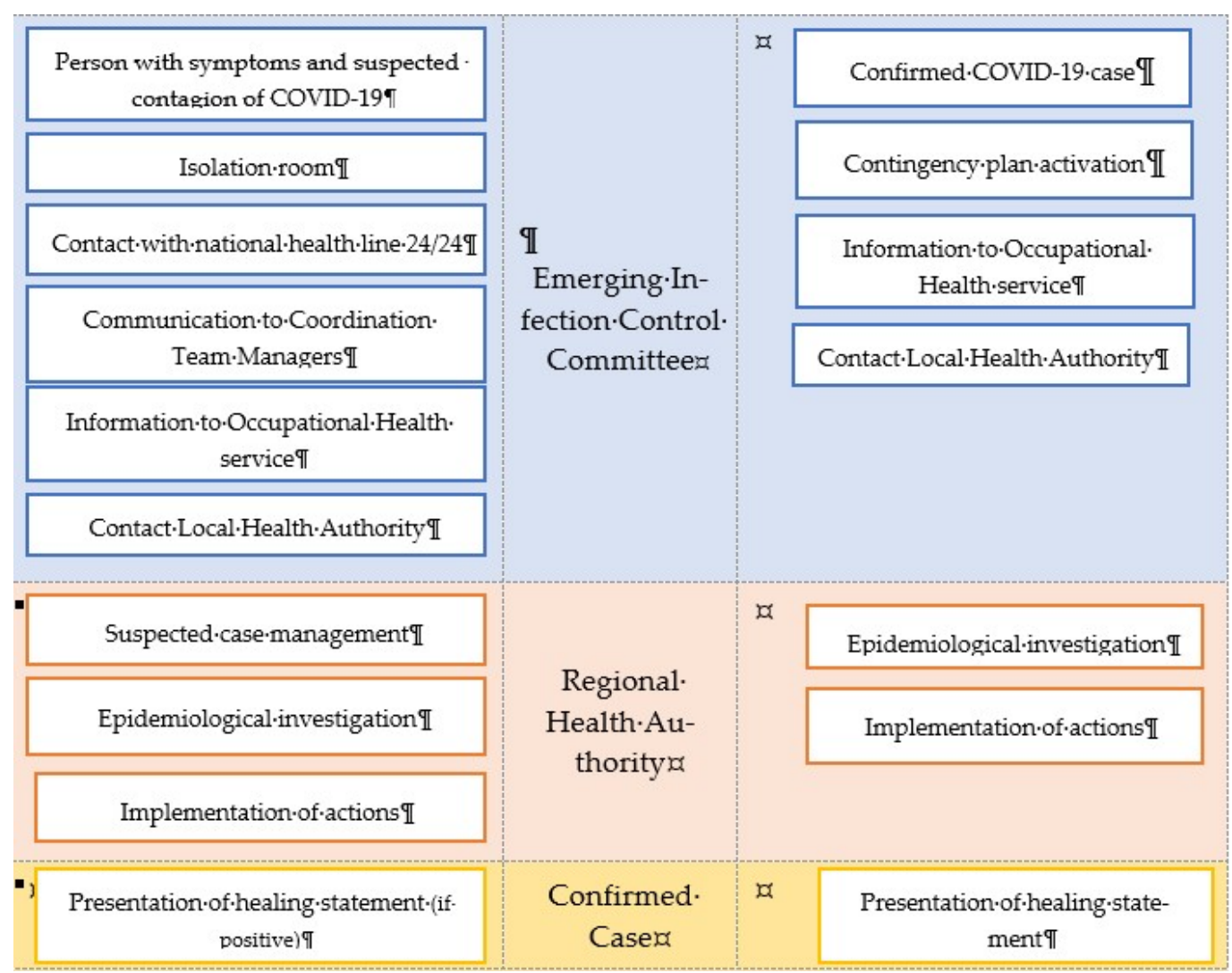

Figure 1. Action flowchart.

To simplify communication and case management, the Committee developed a webbased form to report suspected or confirmed cases of infection. Communication with the regional health authorities is carried out on a weekly basis. Confirmed and suspected cases are daily followed up through telephone by the operational management team.

Depending on the magnitude of SARS-CoV-2 transmission in the academic community, four action scenarios were outlined with concrete and cumulative action measures that, in alignment with the local health authority, provide for action according to the risk assessment.

\begin{tabular}{cc}
\hline "Outbreak" in a class & $\begin{array}{c}\text { Isolation of cases, contact tracking, prophylactic isolation from high- } \\
\text { risk contacts, laboratory tests on high-risk contacts }\end{array}$ \\
\hline $\begin{array}{c}\text { "Outbreak" in several } \\
\text { classes without an epi- } \\
\text { demiological link }\end{array}$ & $\begin{array}{c}\text { Closing of classes with confirmed cases for 14 days from the date of } \\
\text { prophylactic isolation from all contacts; closure of one or more areas of } \\
\text { the school 14 days from the date of commencement of prophylactic isola- } \\
\text { tion from all contacts }\end{array}$ \\
\hline $\begin{array}{c}\text { "Outbreak" in several } \\
\text { classes with an epide- } \\
\text { miological link }\end{array}$ & Extension of isolation measures to low-risk contacts \\
\hline $\begin{array}{c}\text { The Local Health Authority, in conjunction with Regional and National } \\
\text { Health Authorities, may consider the need to scale up measures, as- } \\
\text { transmission control } \\
\text { sessing the temporary closure of the campus. Its reopening should occur } \\
\text { when the Health Authority determines it, based on the epidemiological } \\
\text { situation's control and when it does not represent a risk to the school } \\
\text { community. }\end{array}$ \\
\hline
\end{tabular}

\section{Action Plan}

Since the declaration of the emergency state and in compliance with the Ministry of higher education and health authorities' recommendations, several actions have been taken to protect the safety and health of the academic community. A handrub formulation 
was produced and made available in an initial phase, and a disinfecting footbath mat was placed at strategic entrance points. Cleaning of frequent hand contact surfaces was reinforced, accompanied by the aeration of all locations and adaptation of the ventilation system to negative pressure in classrooms and offices. Alongside the end of the emergency state, academic (face to face) activities were reactivated exclusively for the practical classes with a previous serological antibody (IgG and IgM anti-SARS-CoV-2) testing campaign for the academic community. Exceptional measures were taken, namely the mandatory use of PPE, implementation of barrier methods in the classrooms and public attendance spots and the definition of circulation circuits. Three scenarios for face-to-face academic activities have been outlined: first (50\% of students, a minimum distance of 1 meter between students and 2 meters from the teacher); second (more restrictive, $25 \%$ of the students in the class, a minimum distance of 1.5 meters between students and 2 meters from the teacher) and third (lockdown). A hybrid-operating model was adopted, conditioned by each space's capacity, combining face-to-face and distance activities, assuming the simultaneousness and the alternation of students groups. The creation of "mirror classes" was also privileged, added by the determination of "bubble classes", whenever possible, to prevent possible extended contagion chains.

\section{Final considerations}

As governments continue to respond to COVID-19, it is imperative to follow recommendations that ought to be reasonable and realistic.

The measures engaged, with the primary objective of guaranteeing the safety of the academic community, changed the social reality previously known. Until the present, Coimbra Health School as registered 33 positive cases and 163 contacts regarding prophylactic isolation situations. The established Committee works daily in the pursuit and full application of prevention and protection measures and case management reported by the academic community. While the crisis management strategy presented in this paper is not a measure of its effectiveness, it can be a useful input to other organisations and share the experience perspective. We welcome constructive feedback and collaboration on this challenging mission.

\section{References}

[1] S. Kumar and T. Tripathi, “One year update on the COVID-19 pandemic: Where are we now?," Acta Trop., vol. 214, p. 105778, 2021, doi: 10.1016/j.actatropica.2020.105778.

[2] E. H. Ramírez-Segura, L. G. Motta-Amézquita, P. Flores-Rojas, and L. De Jesús-González, “How to face a massive respiratory epidemic, from the organizational point of view and a contingency plan?," Rev. Mex. Anestesiol., vol. 43, no. 2, pp. 160-167, 2020, doi: $10.35366 / 92877$.

[3] World Health Organisation - WHO, “COVID 19 Weekly Epidemiological update," 2020. [Online]. Available: https://www.who.int/publications/m/item/weekly-epidemiological-update---22-december-2020.

[4] J. Zheng, "SARS-CoV-2: an Emerging Coronavirus that Causes a Global Threat," Int J Biol Sci, vol. 16, no. 10, pp. 1678-85, 2020.

[5] G. J. Patel KP, Vunnam SR, Patel PA, Krill KL, Korbitz PM, “Transmission of SARS-CoV-2: an update of current literature," Eur. J. Clin. Microbiol. Infect. Dis., vol. 39, pp. 2005-11, 2020.

[6] World Health Organisation - WHO, "Critical preparedness , readiness and response actions for COVID-19 .," vol. 2, no. March, pp. 1-3, 2020.

[7] M. Mofijur et al., "Impact of COVID-19 on the social, economic, environmental and energy domains: Lessons learnt from a global pandemic," Sustain. Prod. Consum., vol. 26, no. September 2020, pp. 343-359, 2021, doi: 10.1016/j.spc.2020.10.016.

[8] J. Hellewell et al., "Feasibility of controlling COVID-19 outbreaks by isolation of cases and contacts," Lancet Glob. Heal., vol. 8, no. 4, pp. e488-e496, 2020, doi: 10.1016/S2214-109X(20)30074-7.

[9] A. Tashiro and R. Shaw, "COVID-19 pandemic response in Japan: What is behind the initial flattening of the curve?," Sustain., vol. 12, no. 13, 2020, doi: 10.3390/su12135250.

[10] J. E. Marco-Franco, N. Guadalajara-Olmeda, S. G. de Julián, and D. Vivas-Consuelo, “COVID-19 healthcare planning: Predicting mortality and the role of the herd immunity barrier in the general population," Sustain., vol. 12, no. 13, pp. 1-10, 2020, doi: $10.3390 /$ su12135228.

[11] T. Hale et al., “Variation in government responses to COVID-19 (Version 10.0)," 2020.

[12] Presidência da República, Decreto do Presidente da República n. ${ }^{\circ}$ 14-A/2020, no. 55. 2020, pp. 13(2-4).

[13] P. M. A. R. Correia, I. de O. Mendes, S. P. M. Pereira, and I. Subtil, “The Combat against COVID-19 in Portugal : How State Measures and Data Availability Reinforce Some Organizational Values and Contribute to the Sustainability of the National Health System," Sustainability, vol. 12, no. 18, p. 7513, 2020, doi: doi:10.3390/su12187513. 
[14] M. Oliveira and C. Fernandes, "Managing the Coronavirus Pandemic in Portugal : A Step-by-Step Adjustment of Health and Social Services," Psychol. Trauma Theory, Res. Pract. Policy, vol. 12, no. 5, pp. 536-538, 2020.

[15] V. R. Peixoto, A. Vieira, P. Aguiar, C. Carvalho, D. R. Thomas, and A. Abrantes, "Initial Assessment of the Impact of the Emergency State Lockdown Measures on the 1 st Wave of the COVID-19 Epidemic in Portugal," Acta Med. Port., vol. 33, no. 11, pp. 733-741, 2020, doi: 10.20344/amp.14129.

[16] R. J. Pais and N. Taveira, "Predicting the evolution and control of the COVID-19 pandemic in Portugal [ version 2 ; peer review : 2 approved ]," pp. 1-16, 2020, doi: 10.12688/f1000research.23401.2.

[17] A. Milhinhos and P. M. Costa, “On the Progression of COVID-19 in Portugal : A Comparative Analysis of Active Cases Using Non-linear Regression," Front. Public Heal., vol. 8, no. 495, pp. 1-6, 2020, doi: 10.3389/fpubh.2020.00495.

[18] Presidência do conselho de ministros, Decreto.$^{\circ}$ 11-A/2020, no. 246. 2020, pp. 22(2-40).

[19] XXII Governo da República Portugues, “Estamos ON - A resposta de Portugal à COVID-19." https://covid19estamoson.gov.pt/ (accessed Dec. 28, 2020).

[20] Direção-Geral da Saúde-DGS, “Plano Nacional de Preparação e Resposta à Doença por novo coronavírus (COVID-19)," 2020. [Online]. Available: https://www.dgs.pt/documentos-e-publicacoes/plano-nacional-de-preparacao-e-resposta-para-a-doencapor-novo-coronavirus-covid-19-pdf.aspx.

[21] Ministério da Educação e Ciência, Decreto Regulamentar n. ${ }^{\circ}$ 20/2012. 2012, pp. 627-629.

[22] M. S. Bataineh, Khaleel Bader; Atoum, "A Silver Lining of Coronavirus: Jordanian Universities Turn to Distance Education," Int. J. Inf. Commun. Technol. Educ., vol. 17, no. 2, pp. 138-148, 2021, doi: 10.4018/IJICTE.20210401.oa1.

[23] A. Gobbi, F. Rovea, and P. Italia, "Distance teaching and teaching ' as ' distance . A critical reading of online teaching," Teoría la Educ. Rev. Interuniv., vol. 33, no. 1, pp. 71-87, 2020, doi: 10.14201/teri.23451.

[24] Direção Geral do Ensino Superior, “COVID 19 | Avisos,” 2020. https://www.dges.gov.pt/pt/pagina/covid-19-avisos.

[25] S. e S. S. e da S. Gabinetes das Ministras da Modernização do Estado e da Administração Pública, do Trabalho, Despacho 2836A/2020, no. 43. 2020, pp. 430 (2-4).

[26] European Centre for Disease Prevention and Control, Handbook on simulation exercises in EU public health settings. Stockholm, 2014. 